\title{
Species diversity, abundance, and wildlife conservation status in Batang Gadis National Park, North Sumatra, Indonesia
}

\author{
IFHAM FUADI RAMBE ${ }^{1}$, RIDAHATI RAMBEY ${ }^{2,3, \boldsymbol{v}}$, SAHLAN SIREGAR ${ }^{1}$ \\ ${ }^{1}$ Batang Gadis National Park. Jl. Willem Iskandar, Mandailing Natal 22915, North Sumatra, Indonesia \\ ${ }^{2}$ Department of Forestry, Faculty of Forestry, Universitas Sumatera Utara. Jl. Tridharma Ujung No. 1, Kampus USU, Medan 20155, North Sumatra, \\ Indonesia. Tel.: 061-8220605, `email: ridahati.rambey@usu.ac.id \\ ${ }^{3}$ JATI- Sumatran Forestry Analysis Study Center. Jl. Tri Darma Ujung No. 1 Kampus USU, Medan 20155, North Sumatra, Indonesia
}

Manuscript received: 3 September 2021. Revision accepted: 30 October 2021

\begin{abstract}
Rambe IF, Rambey R, Siregar S. 2021. Species diversity, abundance, and wildlife conservation status in Batang Gadis National Park, North Sumatra, Indonesia. Biodiversitas 22: 5189-5196. Indonesia is one of the countries with the highest biodiversity in the world. Furthermore, the biodiversity of floral and faunal species is still being monitored and maintained, one of which is in the forest of the National Park. Batang Gadis National Park is a habitat for various species of endemic Sumatran wildlife, most of which are endangered species in the world. Therefore, this study aimed to inventory wild animals and to calculate their abundance in the Batang Gadis National Park. The study used camera traps as recording devices that were installed on permanent and non-permanent plots based on evidential animal trajectories in the National Park Management Section Region III Resort 7 Forest of Ampung Padang Forest in 2018. In the permanent plot, 10 species were documented within nine families, namely the Felidae, Tapiridae, Cervidae, Viverridae, Ursidae, Tragulidae, Suidae, Tupaiidae, and the Cercopithecidae. The highest species abundance was Macaca nemestrina (36.17\%), and the second-highest was Muntiacus muntjak Zimmermann (14.89\%), and then Tapirus indicus Desmarest (10,64\%). Also, the Sumatran tiger (Panthera tigris sumatrae Pocock) was in the fourth position with a value of $10.63 \%$ of species abundance. Meanwhile, the lowest abundance index value was from clouded leopard (Neofelis diardi Cuvier) with 2.12\%. The abundance of species from the nonpermanent plots using camera trap documented a total of 13 species with 12 families namely Felidae, Tapiridae, Cervidae, Hystricidae, Viverridae, Muridae, Phasianidae, Tragulidae, Suidae, Muscicapidae, Tupaiidae, and Cercopithecidae. The highest was documented from wild boar (Sus scrofa Linnaeus) at $42.48 \%$ and the second-highest species abundance was macaque (N. nemestrina) at $26.144 \%$. The lowest species abundance index values were tapir (T. indicus) and Javan blue robin (Myiomela diana Lesson) with 0,33\% and 0,33 $\%$, respectively. The existence of documented wildlife species in our study affirmsed the importance of Batang Gadis National Park as a natural habitat for some key and protected species.
\end{abstract}

Keywords: Abundance, biodiversity, Batang Gadis National Park, camera trap, wildlife

\section{INTRODUCTION}

The Indonesian archipelago covers two important biodiversity hotspots in the world with a high number of endemic species while some of the forest regions with high biodiversity are suffering habitat loss and degradation (Rintelen et al. 2017). One of the forest regions in Sumatra with potential biodiversity is Batang Gadis National Park located in Mandailing Natal Regency. The diversity of animal species includes tigers (Panthera tigris sumatrae), forest goats (Naemorhedus sumatrensis), tapirs (Tapirus indicus), sun bears (Helarctos malayanus), sambar deer (Cervus unicolor), Indian muntjak (Muntiacus muntjac), tapirs (T. indicus), hedgehog (Hystrix brachyura), wild boar (Sus scrofa), pig-tailed macaque (Macaca nemestrina), clouded leopard (Neofolis nebulosa), golden cat (Catophama teminckii), and Binturong (Arctistis binturong) (MoF 2005). There are also seven species of primates, namely pig-tailed macaque ( $M$. nemestrina), long-tailed macaque (Macaca fascicularis), simpai/cekcek (Presbytis melalophos sumatrana), buran (Rachypithecus cristatus), ungko (Hylobates agilis), siamang (Symphalangus syndactylus), and slow loris (Nycticebus coucang) (Desmiwati 2016). Furthermore, forest fragmentation that occurs intentionally by anthropogenic activities or unintentionally due to natural disasters can decline animal populations, destroy habitats, and lead to the loss of life in the forest. Therefore, the forest region must be monitored regularly to obtain information on the current wildlife status and the number of its population.

National Parks are the last bastion in the efforts to insitu conserve flora and fauna, especially endangered animals in the world. Batang Gadis National Park is located in the North Sumatra Province, Indonesia, with fairly high terrestrial biodiversity, including endemic Sumatran fauna, namely the Sumatran tiger. However, studies related to fauna in the Batang Gadis National Park are still limited, therefore it is important to conduct this study as a database in the management of the National Park.

This study is expected as a baseline data and reference for developing the number of animal species and their populations from time to time. Therefore, this study aims to (i) make an inventory of animal species found in the PTN Section Region III Resort 7 Forest of Ampung Padang Forest, Batang Gadis National Park, (ii) calculate the abundance of animal species and encounters, and (iii) 
analyze the conservation status of each species at the location.

\section{MATERIALS AND METHODS}

\section{Study area}

The installation location was in the forest of Ampung Padang, Batang Gadis National Park of Mandailing Natal District, North Sumatra, Indonesia (Figure 1). The altitude of the location at each point of the permanent and nonpermanent camera varied from 400-1300 meters above sea level. Furthermore, the camera trap points were spread according to a pre-determined installation plot. Caves formed from rocks were also found along the way and were thought to be a resting place for animals. The shape of the road that varies to the observation plot from sloping, flat, and steep filled with heterogeneous trees makes the Ampang Padang Forest still good for animal habitat.

\section{Data collection}

The camera trap used was a Bushnell type with five units of traps for permanent plots and 10 units for nonpermanent. The camera traps were installed in places that were considered mammalian trajectories. Furthermore, the vegetation on the left-right path of the traps at the installation site was cleared and all the traps were installed at a height of about $50 \mathrm{~cm}$ from the ground. At the time of installation, various conditions included top of the hill, the animal crossing path, the crossroads, a flat hill following the path to the river, the riverbank overgrown with sibarebe (Melastome sp.) as well as at the fork in the animal path in the area. The camera trap installation activities were carried out at intervals of three months, from October to December 2018. All the traps were left for 106 days, and the data were viewed, identified, recapitulated, and analyzed based on the time and number appearance of animals. The number of individuals was calculated with the interval of photos produced every one hour, then the next hour was considered a different individual.

The camera traps were used not only to monitor the presence of animals but can also be used to calculate the relative abundance index (RAI). This index is defined as the abundance of species at a certain location and time in which the unit of measure for relative abundance is correlated with the actual density (Hutajulu 2007).
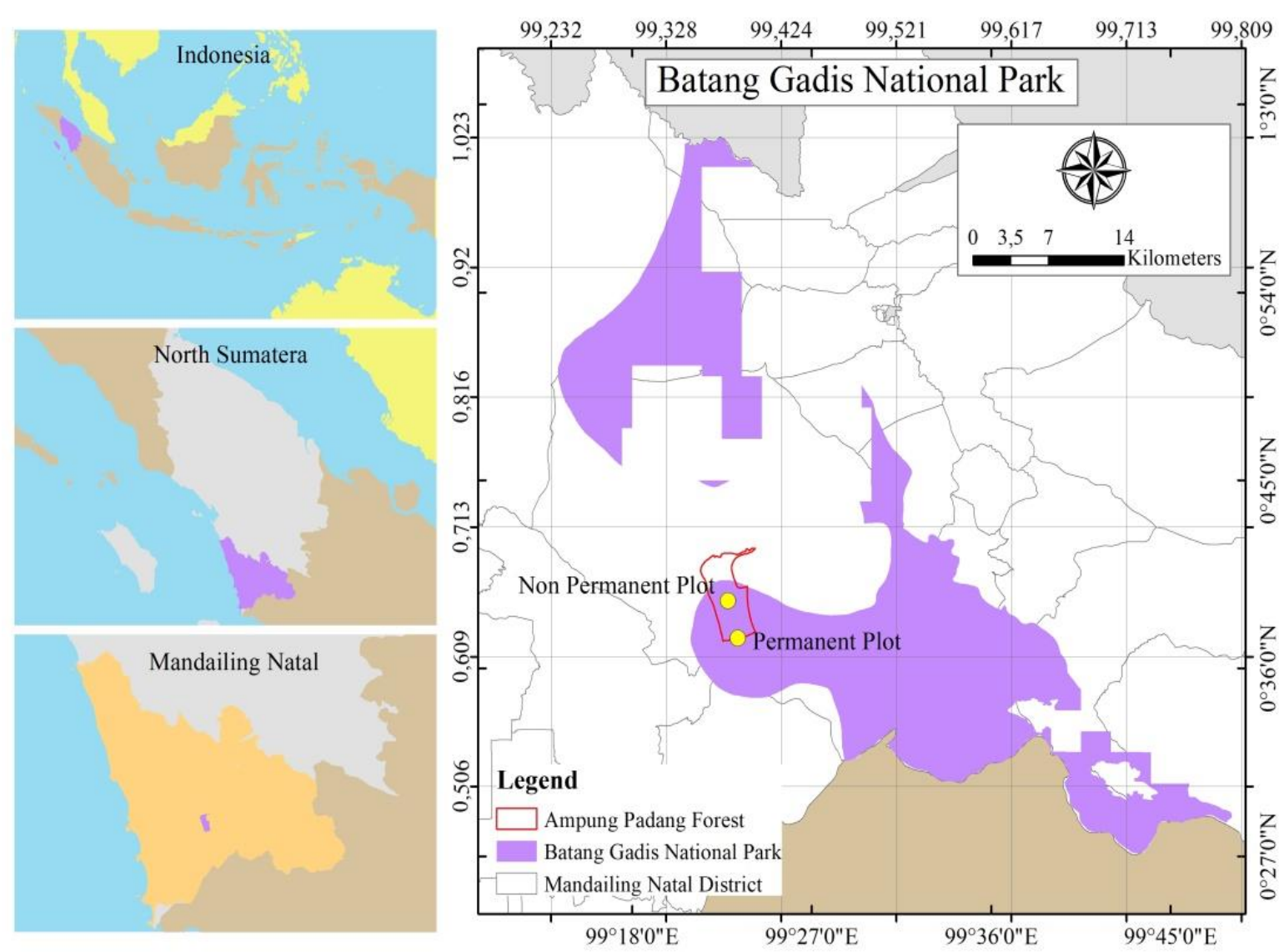

Figure 1. The study area map showing the Permanent and Non-permanent Plots at Ampung Padang Forest, Batang Gadis National Park, North Sumatra, Indonesia 
A permanent plot is a site where the camera trap installation points were made using the $2 \times 2 \mathrm{~km}$ method, adopting the Tropical Ecology Monitoring and Assessment (TEAM) Network tool as a reference from the points made in collaboration with CI-TNBG. Five installed camera traps were in the Batang Gadis National Park area, precisely around the Ampung Padang Forest, National Park Management Section Region III Resort 7. The installation of strategic cameras in one location was very influential in capturing animals, such as discovering feces, traces, scratches, feed, and water sources available at the location. The presence of these signs can be estimated that the animal is caught on the traps. In addition, the permanent plot had an area with a polygon map of 296.43 ha. The rate of encounters was obtained by calculating the number of animal pictures obtained divided by the number of days the camera was active.

A non-permanent plot was established outside the permanent, where camera traps were installed on animal tracks with a minimum distance of $1 \mathrm{~km}$ between camera traps. The non-permanent plot area was 119.08 ha. Furthermore, as many as 10 camera traps were installed, where one point was installed opposite each other because the location was considered strategic as the trajectory of the Sumatran tiger (Panthera tigris sumatrae) which was a key animal in Batang Gadis National Park, then nine camera trap points were installed in the site.

\section{Data analysis}

Species abundance was calculated using the following formula (Brower and Zar 1977):

$$
\mathrm{P}_{\mathrm{si}}=\underline{\mathrm{ni}} \times 100 \%
$$

Where:

Psi : Percentage value of the $\mathrm{i}^{\text {th }}$ species abundance

ni : Number of individuals of the $\mathrm{i}^{\text {th }}$ type

$\mathrm{N}$ : Number of individuals of all species

The encounter rate was obtained by calculating the total number of photos divided by the total number of days. The camera was actively multiplied by one hundred. The divisor factor is 100 days to equalize the unit of business used (O'Brien et al. 2003)

$$
\begin{aligned}
& \sum \mathrm{ER}=\sum \mathrm{f} \times 100 \\
& \quad \sum \mathrm{d} \\
& \text { Where: } \\
& \mathrm{ER}: \text { Encounter rate } \\
& \sum \mathrm{f} \quad: \text { Total number of photos obtained } \\
& \sum \mathrm{d} \quad: \text { Total number of camera operating days }
\end{aligned}
$$

\section{Shannon-Wiener index ( $\left.H^{\prime}\right)$}

The level of species diversity Shannon-Wienner index ( $\left.H^{\prime}\right)$ was classified into high $\left(\mathrm{H}^{\prime}>3\right)$, medium $\left(1 \leq \mathrm{H}^{\prime} \leq 3\right)$, and low $\left(\mathrm{H}^{\prime}<1\right)$. Species diversity can be calculated using the Shannon-Wiener diversity index with the following formula (Odum 1996).

$$
\text { Shannon's diversity index }\left(H^{\prime}\right)=-\sum_{i=1}^{s} p i \ln p i
$$

Where:

$\mathrm{p} \quad$ : The proportion of $(\mathrm{n} / \mathrm{N})$

$\mathrm{n} \quad$ : Number of individuals of one species

$\mathrm{N}$ : Total number of individuals of all species

\section{Evenness index ( $\left.J^{\prime}\right)$}

Ludwig and Reynolds (1988) stated that the proportion of mammal species calculated using index evenness is:

$$
\begin{aligned}
& \mathrm{J}^{\prime}=\mathrm{H}^{\prime} / \mathrm{Ln} \mathrm{S} \\
& \text { Where: } \\
& \mathrm{J}^{\prime} \quad: \text { Specific evenness index } \\
& \mathrm{H}^{\prime} \quad: \text { Shannon Wiener diversity index } \\
& \mathrm{S} \quad \text { : Number of species found } \\
& \text { Evenness index ranges from } 0 \text { up to } 1
\end{aligned}
$$

Margalef's index

Margalef's species richness was calculated using the formula (Magurran 1988):

$$
D_{m g}=\frac{S-1}{\operatorname{Ln} N}
$$

Where, $D_{m g}$ is Margalef's species richness indicator, $S$ is the number of documented species. $N$ is the total number of individuals and $\ln$ is a natural logarithmic value. The level of species richness is classified as high $\left(D_{m g}>5\right)$, moderate $\left(3.5 \leq D_{m g} \leq 5\right)$, and low $\left(D_{m g}<3.5\right)$.

\section{RESULTS AND DISCUSSION}

Fifteen wildlife species were documented in Region III Resort 7 Ampung Padang, Batang Gadis National Park. The wildlife species comprised 12 families, namely Cervidae, Cercopithecidae Felidae, Muridae, Muscicapidae Phasianidae, Tapiridae, Tragulidae, Tupaiidae, Ursidae, and Viverridae. The wildlife species are listed in Table 1.

Eight species were found in both permanent and nonpermanent plots, namely Panthera tigris sumatrae Pocock, Tapirus indicus Desmarest, Muntiacus muntjak Zimmermann, Paradoxurus hermaphroditus Pallas, Tragulus kanchil Raffles, Sus scrofa Linnaeus, Tupaia glis Diard, and Macaca nemestrina Linnaeus (Tables 2 and 3). The results of wildlife monitoring using camera traps were highly variable depending on the geographical location. In contrary, Mustari et al. (2015), they documented 23 species of animals found in Mount Halimun Salak National Park using 31 camera trap units. Compared to Rimaze (2020), there were 21 species of mammals in the Kwakuchinja Wildlife Corridor. Based on Scullion (2021) on the Peru Ichigkat Muja border-Cordillera del Condor National Park, during the two field seasons, a total of 26 species from 19 families were recorded using camera traps. Clements et al. (2021) during 4054 days of camera traps reported 31 mammalian species found in Taman Nagara Landscape Malaysia. Some were endangered species such as the Malayan tiger (Panthera tigris jacksoni), Dhole (Cuon alpinus), Malayan pangolin (Manis javanica), Asian elephant (Elephas maximus), and Malayan tapir ( $T$. indicus). Compared with other studies, installing camera 
traps for permanent and non-permanent plots in our study is still ineffective in capturing the maximum number of wildlife species wandering in the area. Permanent recording using camera traps is meant to minimize the missing events of an animal species while in this study the proportion of unrecorded species in permanent plots is quite high when compared to other non-permanent plots (Jumeau et al. 2017). It is suggested for further monitoring, the placement of camera traps must be improved.

Panthera tigris sumatrae, is a felid species with a narrow distribution that can be only found on Sumatra Island, especially in lowland forests to the mountains. Furthermore, the distribution area is at an altitude of 0 $2000 \mathrm{~m}$ above sea level (O'Brien et al. 2003; Dinata 2008), but sometimes to more than 2,400 m (Linkie et al. 2003; Dinata 2008). The International Union for Conservation of Nature (IUCN) has categorized this species as critically endangered (Rifaie et al. 2015). The Sumatran tiger population continues to decline, in its natural habitat, and only about 500 individuals remain and some occupy fragmented forests (Kenney et al. 2014; Goodrich et al. 2015; Joshi et al. 2016; Harihar et al. 2017; Master et al. 2021). This condition is a crucial challenge for the conservation of this wildlife. P. tigris faces a high risk of extinction because the number of wild animals has drastically decreased due to hunting and habitat destruction, hence, ex-situ conservation programs (habituation of tigers at the zoo) are crucially needed (Narayan et al. 2013). The P. tigris sumatrae belongs to the family Felidae. Also, the important role of Felidae in the ecosystem may be defined as a guardian of ecosystem stability. In addition to being a large predator, another role is as an umbrella species considering the need for large areas to meet needs including food, protection, and space (Putri et al. 2017).

Tapirus indicus (tapirs) is herbivore, especially the young leaves and fruits that fall on the forest floor. Tapirs play a role as seed dispersers and are important for maintaining forest ecosystems. The decline in their populations is due to habitat degradation and threats, while the biggest threat is from humans through hunting and illegal trade (Setiawan 2013). MacKinnon (1984) and Farida et al. (2006) reported that the tapir habitat is a tropical rain forest with an altitude of 300-2000 m above sea level. In Sumatra, tapirs are scattered in several habitats, such as swamp, peat, lowland, as well as low and high mountain forests.

Muntiacus muntjak is an animal that lives in solitude and the forest. Pokharel et al. (2010) in the mountain forest region of Hemja VDC, Kaski District, Nepal showed the distribution of the salak deer (M. muntjak) was clustered and uneven. The species prefers central mountains (1100$1300 \mathrm{~m}$ ) with dense canopy cover, decent water sources, and less human disturbance.

Paradoxorus hermaphroditus is rainforest animals or civet with an important role in plant regeneration through seed dispersal (Mudappa et al. 2010; Nakashima et al. 2013; Winaya et al. 2020). However, the International Union for Conservation of Nature (IUCN) categorizes civet on the list of least concern. This means the species has the least attention because the population is considered large, therefore, they are not threatened by extinction (Duckworth et al. 2016; Winaya et al. 2020).

Tragulus kanchil is one of the animal species found in Batang Gadis National Park. According to the IUCN Redlist, the mouse deer is included in the status of least concern. The species is a small hoofed animal without horns and lives in tropical Asia and Africa. Little has been published on ecology and its role in the tropical forest ecosystem in this area.

Sus scrofa is a large mammal that lives in dense forests. In the IUCN status, wild boar is included in the least concerned, meaning that the presence in nature is still abundant. Wild boar feed is dominated by plant material (90\%) consumed in quite large proportions because of its large body (Ballari 2013). Wild boar has the habit of seriously exploring the forest floor in search of food (Lyang and Lee 2010; Kim et al. 2019). Therefore, feeding activities will greatly affect the structure and function of forest ecosystems (Focardi et al. 2000; Hone 2002; Kim et al. 2019).

Table 1. Wildlife species in Region III Resort 7 Ampung Padang, Batang Gadis National Park, North Sumatra, Indonesia

\begin{tabular}{|c|c|c|c|c|c|c|}
\hline $\begin{array}{c}\text { Indonesian } \\
\text { name }\end{array}$ & English name & Scientific name & Family & $\begin{array}{c}\text { Permanent } \\
\text { plot }\end{array}$ & $\begin{array}{c}\text { Non-permanent } \\
\text { plot }\end{array}$ & $\begin{array}{c}\text { Conservation } \\
\text { status } *)\end{array}$ \\
\hline \multicolumn{2}{|c|}{ Harimau sumatera Sumatran tiger } & Panthera tigris sumatrae Pocock & Felidae & + & + & Endangered \\
\hline Tapir & Tapir & Tapirus indicus Desmarest & Tapiridae & + & + & Endangered \\
\hline Kijang & Indian muntjac & Muntiacus muntjak Zimmermann & Cervidae & + & + & Least concern \\
\hline Macan dahan & Clouded leopard & Neofelis diardi Cuvier & Felidae & + & & Vulnerable \\
\hline Musang & Weasel & Paradoxurus hermaphroditus Pallas & Viverridae & + & + & Least concern \\
\hline Beruang madu & Honey bear & Helarctos malayanus Raffles & Ursidae & + & - & Vulnerable \\
\hline Kancil & Mouse deer & Tragulus kanchil Raffles & Tragulidae & + & + & Least concern \\
\hline Babi hutan & Wild boar & Sus scrofa Linnaeus & Suidae & + & + & Least concern \\
\hline Tupai akar & Squirrel root & Tupaia glis Diard & Tupaiidae & + & + & Least concern \\
\hline Beruk & Pig-tailed macaque & Macaca nemestrina Linnaeus & Cercopithecidae & + & + & Vulnerable \\
\hline Landak & Malayan porcupine & Hystrix brachyura Linnaeus & Porcupine & - & + & Least concern \\
\hline Tikus hutan & Long-tailed field mouse & Apodemus sylvaticus Linnaeus & Muridae & - & + & Least concern \\
\hline Sampidan biru & Blue champ & Lophura ignita Shaw & Phasianidae & - & + & Near threatened \\
\hline Puyuh sengayan & Sengayan quail & Rollulus rouloul Shaw & Phasianidae & - & + & Near threatened \\
\hline Burung bekecet & Squeaky bird & Myiomela diana Lesson & Muscicapidae & - & + & Least consern \\
\hline
\end{tabular}

Notes: (+): Documented, (-): Absent; *)IUCN Redlist (2021) 
Table 2. Species abundance, animal encounters on permanent plots

\begin{tabular}{|c|c|c|c|c|c|}
\hline Scientific name & $\begin{array}{l}\text { Number of } \\
\text { individuals }\end{array}$ & $\begin{array}{c}\text { Abundance } \\
(\%)\end{array}$ & Animal encounter & Number of photos & Number of events \\
\hline Macaca nemestrina Linnaeus & 17 & 36.17 & 23.58 & 25 & 16 \\
\hline Muntiacus muntjak Zimmermann & 7 & 14.89 & 10.38 & 11 & 9 \\
\hline Tapirus indicus Desmarest & 5 & 10.64 & 4.72 & 5 & 5 \\
\hline Panthera tigris sumatrae Pocock & 4 & 8.51 & 4.72 & 5 & 5 \\
\hline Helarctos malayanus Raffles & 3 & 6.38 & 2.83 & 3 & 3 \\
\hline Tupaia glis Diard & 3 & 6.38 & 3.77 & 4 & 4 \\
\hline Sus scrofa Linnaeus & 3 & 6.38 & 2.83 & 3 & 1 \\
\hline Tragulus kanchil Raffles & 2 & 4.26 & 1.89 & 2 & 2 \\
\hline Paradoxurus hermaphroditus Pallas & 2 & 4.26 & 1,89 & 2 & 2 \\
\hline Neofelis diardi Cuvier & 1 & 2.13 & 0.94 & 1 & 1 \\
\hline Total & 47 & 100 & 57.55 & 61 & 48 \\
\hline
\end{tabular}

Table 3. Wildlife species abundance in non-permanent plots

\begin{tabular}{|c|c|c|c|c|c|}
\hline Scientific name & $\begin{array}{l}\text { Number of } \\
\text { individuals }\end{array}$ & $\begin{array}{c}\text { Abundance } \\
(\%)\end{array}$ & Animal encounter & Number of photos & Number of events \\
\hline Sus scrofa Linnaeus & 130 & 42.48 & 155.66 & 165 & 115 \\
\hline Macaca nemestrina Linnaeus & 80 & 26.14 & 81.13 & 86 & 59 \\
\hline Lophura ignita Shaw & 34 & 11.11 & 33.96 & 36 & 28 \\
\hline Rollulus rouloul Shaw & 19 & 6.21 & 22.64 & 24 & 3 \\
\hline Tragulus kanchil Raffles & 14 & 4.58 & 13.21 & 14 & 14 \\
\hline Muntiacus muntjak Zimmermann & 7 & 2.29 & 6.60 & 7 & 7 \\
\hline Tupaia glis Diard & 6 & 1.96 & 5.66 & 6 & 6 \\
\hline Paradoxurus hermaphroditus Pallas & 4 & 1.31 & 4.72 & 5 & 5 \\
\hline Apodemus sylvaticus Linnaeus & 5 & 1.63 & 4.72 & 5 & 5 \\
\hline Hystrix brachyuran Linnaeus & 3 & 0.98 & 2.83 & 3 & 3 \\
\hline Panthera tigris sumatrae Pocock & 2 & 0.65 & 1.89 & 2 & 2 \\
\hline Myiomela diana Lesson & 1 & 0.33 & 1.89 & 2 & 2 \\
\hline Tapirus indicus Desmarest & 1 & 0.33 & 0.94 & 1 & 1 \\
\hline Total & 306 & 100 & 335.85 & 356 & 250 \\
\hline
\end{tabular}

Tupaia glis is a squirrel species with a head and body length of about $15 \mathrm{~cm}$ or less and a tail of about $18 \mathrm{~cm}$. According to Mustari et al. (2015), T. glis is a mammalian species that has a wide distribution compared to other mammals. This is because of their lifestyle as arboreal animals that require trees as a place to eat.

Macaca nemestrina or pig-tailed macaque is distributed over a wide area, including Indonesia, Malaysia, Thailand, and China. The body mass of the males $(15 \mathrm{~kg})$ and females $(11 \mathrm{~kg})$ is distinguishable. Ahmadi et al (2016) stated that the home range size of the macaque $(M$. nemestrina) is 125 ha, with an average daily travel distance of $1900 \mathrm{~m}$.

In the permanent plots, ten species of wildlife animals were documented with a total of 47 individuals and nine families namely the Felidae, Tapiridae, Cervidae, Viverridae, Ursidae, Tragulidae, Suidae, Tupaiidae, and Cercopithecidae. The data on the number of individuals, the abundance of species, and encounters of animals can be seen in Table 2.

Southern pig-tailed macaque (M. nemestrina) was the most common (highest abundance) species found in permanent plots with 17 individuals $(36.17 \%)$, followed by deer (M. muntjak) with seven individuals (14.89\%), and tapir (T. indicus) with five individuals $(10.63 \%)$. Thus, the existence of macaque ( $M$. nemestrina) is supported by the available feed. In addition, habitat conditions also affect the abundance of existing animals. Therefore, the importance of the existence of sources of food, water, shelter, and cover is very supportive of animal life.

The key species, the Sumatran tiger (P. tigris sumatrae) was in the fourth position with an abundance of $8.51 \%$. The animal with the lowest abundance of 10 species found using camera traps was the clouded leopard (Neofelis diardi Cuvier) with an abundance of $2.31 \%$. According to Brower and Zar (1997), abundance is the number of individual species. The abundance is a value or indicator 197 of the dominance of a wild animal species compared to the number of other individual species. The result of our study was due to the low level of encounters with camera traps which was less than five camera traps while two other cameras were damaged in the field leading to the low abundance of some species.

The rate of the encounter was shown by the number of times the animals were captured on the camera. In general, most species have a high sensitivity level and prefer to avoid humans, indicating a low encounter level. Meanwhile, in some habitats, animals are directly found because of good support to life. This explains that camera utilization is highly effective to calculate the level of 
encounters. Therefore, the encounter rate was generated by dividing the number of animal pictures by the number of camera active days.

From the results of the inventory and monitoring, the Sumatran tigers were found in the forest around the village of Ampung Padang. This is due to the availability of sufficient feed and the camera installation is put in a forest location with a dense canopy. Tigers are found in various types of habitat as long as there is sufficient food available in the form of prey animals, available water sources, and protection from the sun. In addition, tigers do not like hot weather and generally seek a shady place to rest.

In the non-permanent plots, 13 animal species were found within 12 families, namely the Felidae, Tapiridae, Cervidae, Hystricidae, Viverridae, Muridae, Phasianidae, Tragulidae, Suidae, Muscicapidae, Tupaiidae, and Cercopithecidae. Based on the camera trap installation results, the highest species abundance was $S$. scrofa $(42.48 \%)$, and the second-highest was $M$. nemestrina
Linnaeus (26.14\%). Meanwhile, the lowest abundance values were $T$. indicus $(0.32 \%)$ and Myiomela diana Lesson $(0.32 \%)$. Species abundance is a value or indicator of the dominance of a wild animal in a habitat. It also describes how much the number of a species is compared to the number of individual types of other animals. Furthermore, abundance is the ratio of the number of species to the total number of individuals present (Avolio et al. 2019). The existence of the wild boar (S. scrofa) is supported by the available feed on site. Also, habitat conditions affect the abundance of existing animals. The availability of food, water, shelter, and cover is important to support animal life. Therefore, the level of encounter is very difficult to find in nature. However, in certain habitats, animals can often be found directly because the habitat is very supportive of their lives. This explains that the indirect method of using camera traps can be used to calculate the level of encounters. Some of the wildlife species found can be seen in Figure 2.
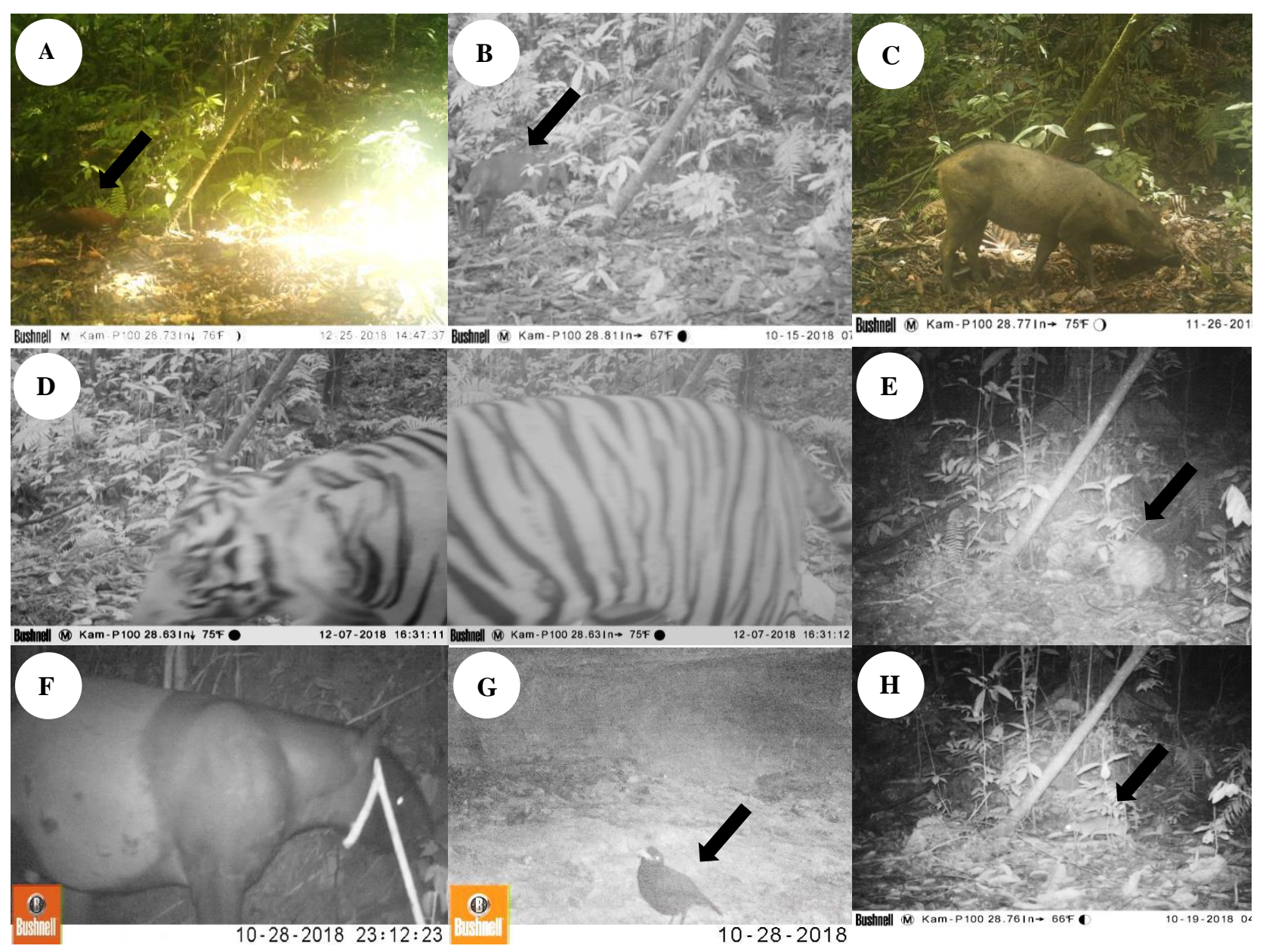

Figure 2. Some of the wildlife found in Batang Gadis National Park A. Lophura ignita Shaw, B. Muntiacus muntjak Zimmermann, C. Sus scrofa Linnaeus, D. Panthera tigris sumatrae Pocock, E. Hystrix brachyura Linnaeus, F. Tapirus indicus Desmarest, G. Myiomela diana Lesson, H. Tragulus kanchil Raffles 
Table 4. Shannon's Diversity Index $\left(H^{\prime}\right)$, Evenness Index $\left(J^{\prime}\right)$, and Margalef's species richness (Dmg) Ampung Padang Forest, Batang Gadis National Park, North Sumatra, Indonesia

\begin{tabular}{lcccccc}
\hline \multicolumn{1}{c}{ Population } & $\begin{array}{c}\text { Shannon's diversity } \\
\text { index }\left(\boldsymbol{H}^{\prime}\right)\end{array}$ & Category & $\begin{array}{c}\text { Evenness } \\
\text { index }\left(\boldsymbol{J}^{\prime}\right)\end{array}$ & Category & $\begin{array}{c}\text { Margalef's species } \\
\text { richness }(\boldsymbol{D m g})\end{array}$ & Category \\
\hline Permanent plot & 1.97 & Moderate & 0.85 & Even & 2.39 & Low \\
Non-permanent plot & 1.67 & Moderate & 0.12 & Uneven & 2.09 & Low \\
\hline
\end{tabular}

The value of Shannon's Diversity Index $\left(H^{\prime}\right)$ for the permanent plot was 1.97 , and 1.67 for the non-permanent (Table 4). This indicates that the $\mathrm{H}^{\prime}$ of each plot is in the moderate category. Meanwhile, the value of the medium category means that the condition of the Mammal species in the reclamation area has sufficient productivity. Also, the condition of the ecosystem is quite balanced and the ecological pressure is still moderate (Barbour et al.,1987). The Evenness Index $\left(J^{\prime}\right)$ value on the permanent plot was 0.85 and categorized in the moderate category or evenly distributed. Meanwhile, the Evenness Index $\left(J^{\prime}\right)$ value in the non-permanent plot was 0.12 and categorized as uneven or dominated by certain species (Table 4).

The value of Margalef's species richness $(D m g)$ on the permanent plot was 2.39, and 2.09 on the non-permanent (Table 4). This means the Dmg value is in a low category. In accordance with Kirmi et al. (2019) who studied reclamation of Berau Coal company in East Kalimantan, the value of mammalian diversity was found almost evenly in all observation locations, namely in the medium category with H' values of 2.45 in Lati, 2.67 in Binungan, and 2.52 in Sambarata.

\section{ACKNOWLEDGEMENTS}

The authors are grateful to the Head of Batang Gadis National Park (Ir. Sahdin Zunaidi, M.Si), Head of SubDivision of Administration (Bobby Nopandry, S.Hut, MA), Head of Section of PTN Region III Resort 7 (Siti Wahyuna, SP), and the Forest Ecosystem Controller Team for their support during this study in the field.

\section{REFERENCES}

Ahmadi ES, Oktorini Y, Defri Yoza. 2016. Identifikasi daerah jelajah beruk (Macaca nemestrina Linnaeus, 1766) menggunakan aplikas sistem informasi geografis di kawasan hutan Universitas Riau. Jurnal Online Mahasiswa Fakultas Pertanian Universitas Riau 32: 1-12. [Indonesian]

Avolio ML, Forrestel EJ, Chang CC, Pierre KJL, Burghardt KT, Smith MD. 2019. Demystifying dominant species. J Phytologist 223 (3): 1106-1126. DOI: $10.1111 / \mathrm{nph} .15789$.

Brower JE, Zar JH. 1977. Field and Laboratory Methods for General Ecology. Wm. C. Brown Company Publisher, Dubuque Iowa.

Ballari SA, Barrios-García MN. 2013. A review of wild boar Sus scrova diet and factors affecting food selection in native and introduced ranges. Mammal Rev 44: 124-134. DOI: 10.1111/mam.12015.

Clements GR, Rostro-García S, Kamler JF, Liang SH, Hashim AKBA. 2021. Conservation status of large mammals in protected and logged forests of the greater Taman Negara Landscape, Peninsular Malaysia. Biodiversitas 22: 272-277. DOI: 10.13057/biodiv/d220133.
Dinata, Sugardjito D. 2008. The existence of Sumatran tiger (Panthera tigris sumatrae Pocock, 1929) and their prey in different forest habitat types in Kerinci Seblat National Park, Sumatra. Biodiversitas 9: 222226. DOI: 10.13057/biodiv/d090315.

MoF. 2005. Rencana Pengelolaan Taman Nasional Batang Gadis (RPTNBG). Direktorat Jenderal Perlindungan Hutan dan Konservasi Alam. Balai Konservasi Sumber Daya Alam Sumatera Utara II, Medan. [Indonesian]

Desmiwati S. 2016. Upaya penyelesaian masalah pemantapan kawasan hutan pada Taman Nasional di Pulau Sumatra. Jurnal Penelitian Kehutanan Wallacea 6 (2): 135-146. [Indonesian]

Farida WR, Wirdateti, Dahruddin H, Sumaatmadja G. 2006. Habitat dan keragaman tumbuhan pakan bagi tapir (Tapirus indicus), kijang (Muntiacus muntjak) dan kukang (Nycticebus coucang) di Kawasan Gunung Tujuh, Taman Nasional Kerinci Seblat, Jambi. Jurnal Peternakan Indonesia 11: 7-17. [Indonesian]

Hutajulu MB. 2007. Studi Karakteristik Ekologi Harimau Sumatera [Panthera tigris sumatrae (Pocock 1929)] Berdasarkan Camera Trap di Lansekap Tesso Nilo-Bukit Tigapuluh, Riau. [Tesis]. Universitas Indonesia, Jakarta. [Indonesian]

Kim Y, Cho S, Choung Y. 2019. Habitat preference of wild boar (Sus scrofa) for feeding in cool-temperate forests. J Ecol Environ 43: 30. DOI: 10.1186/s41610-019-0126-3.

Kirmi H, Anwar S, Masyhuri M, Prasetiyo DE. 2019. Tingkat kehadiran dan keanekaragaman jenis mammalia di areal reklamasi PT. Berau Coal, Kalimantan Timur. Jurnal Biologi dan Pendidikan Biologi 5 (1): 35-45. [Indonesian]

Ludwig JA, JF Reynold. 1998. Statistical Ecology: A Primer on Methods and Computing. John Wilwy \& Sons, New York.

Magurran AE. 1988. Ecological Diversity and Its Measurement. Princeton University Press, Princeton.

Master J, Qayim I, Setiadi D, Santoso N. 2021. The increase of Sumatran tiger's prey following eradication of Melastoma malabatrichum in Way Kambas National Park, Indonesia. J Trop Biodiver Biotechnol 6: 1-13. DOI: 10.22146/jtbb.63972.

Mustari AH, Setiawan A, Rinaldi D. 2015. Kelimpahan jenis mamalia menggunakan kamera jebakan di resort Gunung Botol Taman Nasional Gunung Halimun Salak. Media Konservasi 20 (2): 93-101. [Indonesian]

Narayan EJ, Parnell T, Clark G, Vegue P M. Mucci A, Hero JM. 2013. Faecal cortisol metabolites in Bengal (Panthera tigris tigris) and Sumatran tigers (Panthera tigris sumatrae). J General Comparative Endocrinol 194: 318-325. DOI: 10.1016/j.ygcen.2013.10.002.

Odum EP. 1996. Dasar-dasar Ekologi (Ecology Fundamentals). Gadjah Mada University Press, Yogyakarta. [Indonesian]

Putri RAA, Mustrai AH, Ardiantino. 2017. Keanekaragaman jenis Felidae menggunakan camera trap di Taman Nasional Bukit Barisan Selatan. Jurnal Penelitian Hutan dan Konservasi Alam 14: 21-24. [Indonesian]

Pokharel K, Chalise MK. 2010. Status and distribution pattern of barking deer (Muntiacus muntjak Zimmermann) in Hemja VDC, Kaski Nepal. J Sci Technol 11: 223-228. DOI: 10.3126/njst.v11i0.4149.

Rifaie F, Sugardjito J, Fitriana YS. 2015. Spatial point pattern analysis of the Sumatran tiger (Panthera tigris sumatrae) poaching cases in and around Kerinci Seblat National Park, Sumatra. Biodiversitas 16: 311319. DOI: $10.13057 /$ biodiv/d160228 .

Rimaze D, Machumua A, Mremi R, Eustace A. 2020. Diversity and abundance of wild mammals between different accommodation facilities in the Kwakuchinja Wildlife Corridor. J Sci Afr 9: e00480. DOI: 10.1016/j.sciaf.2020.e00480.

Rintelen KV, Arida E, Hauser C. 2017. A review of biodiversity-related issues and challenges in megadiverse Indonesia and other Southeast Asian countries. Res Idea Outcomes 3: e20860. DOI: 10.3897/rio.3.e20860. 
Scullion PJJ, Fahrenholz J, Huaytalla V, Rengifo EM, Lang E. 2021. Mammal conservation in Amazonia's protected areas: A case study of Peru's Ichigkat Muja - Cordillera del Condor National. J Glob Ecol Conserv 26: e01451. DOI: 10.1016/j.gecco.2021.e01451.

Setiawan YA, Kanedi M, Sumianto, Subagyo A, Alim N, Apriawan, Yunus M. 2013. Kajian Keberadaan Tapir (Tapirus indicus) di Taman Nasional Way Kambas Berdasarkan Jebakan Kamera. Seminar
Nasional Sains dan Teknologi V, Lembaga Penelitian Universitas Lampung, 19-20 November 2013. [Indonesian]

Winaya A, Maftuchah, Nicolas CM, Prasetyo D. 2020. Morphometric variations of Asian common palm civet (Paradoxurus hermaphroditus, Pallas 1777) from Bali Island, Indonesia as the basis of morphometrics diversity data. Biodiversitas 21: 1027-1034. DOI: 10.13057/biodiv/d210324. 